J. Perinat. Med. 17 (1989) 203

\title{
Simplified quantitative determination of phospholipids in amniotic fluid, alveolar lavages and milk using high performance liquid chro- matography (HPLC)
}

\author{
Geno Kynast and Christiane Schmitz \\ Institute of Perinatal Medicine, Free University of Berlin and Department of \\ Obstetrics of the Women's Hospital, Berlin-Neukölln, West Germany
}

\section{Introduction}

Through the introduction of high performance liquid chromatography (HPLC) into the analytics of phospholipids (PL) it has become possible to detect the main PL in amniotic fluid quantitatively and with high sensitivity. So HPLC has enabled advances in fetal lung maturity determination as one of the main problems in perinatology $[1,2$, 3]. Nevertheless quantitation by HPLC is limited due to the absence of a universal detector to measure molar quantities. UV detection is convenient but has the disadvantage that carbon double bounds of unsaturated PL produce higher UVsignals than the carbonyl groups of the disaturated dipalmitoyl lecithin as the main component of the surfactant lecithin.

On the other hand HPLC detection systems like fluorescence detection [7] or differential refractometric (RI) detection [4] are very sophisticated and the determinations are very time consuming because of post column derivatisation of the compounds [7]. Identification of PL by mass detection is even more expensive, time consuming and difficult to handle [9].

For clinical use these detection methods are no alternatives for easy to handle UV-equipment, if the influence of the unsaturated PL-compounds is minimized by optimized column separation conditions.

Publications of Pison et al. [6] and D'Costa et al. [2] validate the HPLC-UV-results by comparison with thinlayer chromatographic determination, but the demonstrated HPLC chromatograms [2] (figure 1) are unsatisfactory. So the first aim of our work had to be the optimisation of the column conditions.

Since phospholipids are not only to be found in amniotic fluid they are of general interest. So it seemed to be important to check the validity of the method in other biological fluids like tracheal secretion, gastric aspirate, lung lavages, human milk, cow's milk and also in infant formulas. Therefore the second aim of our work was to extend the spectrum of application of our HPLC method. The necessary improvements and modifications can be summarized in two points:

a) Alteration of the extraction procedure to complete the extraction of phosphatidylethanolamine (PE) and phosphatidylinositol (PI) in order to make a second extraction superfluous. This second extraction is very time consuming and cannot be performed in media like milk and tracheal secretion due to the presence of other ingredients, for example, high fat contents.

b) Improvement of the layer separation, since there is no separation of the extraction layers in amniotic fluid samples containing large amounts of meconium.

\section{Materials and methods}

\subsection{Standards and reagents}

The following phospholipids listed were purchased from SIGMA (Munich, FRG): phosphatidylglycerol (PG) (ammonium salt, egg yolk), phosphatidylinositol (PI) (ammonium salt, soybean) phosphatidylethanolamine (PE) (lecithin typ III, egg 
yolk), phosphatidylcholine (PC) (lecithin type III $\mathrm{E}$, egg yolk) sphingomyelin (SP) .(bovine brain) and lysolecithin (LL) (type I, soybean). Acetonitril (HPLC-grade) was obtained from PROMOCHEM (Hamburg-Wesel, FRG). We use chloro-

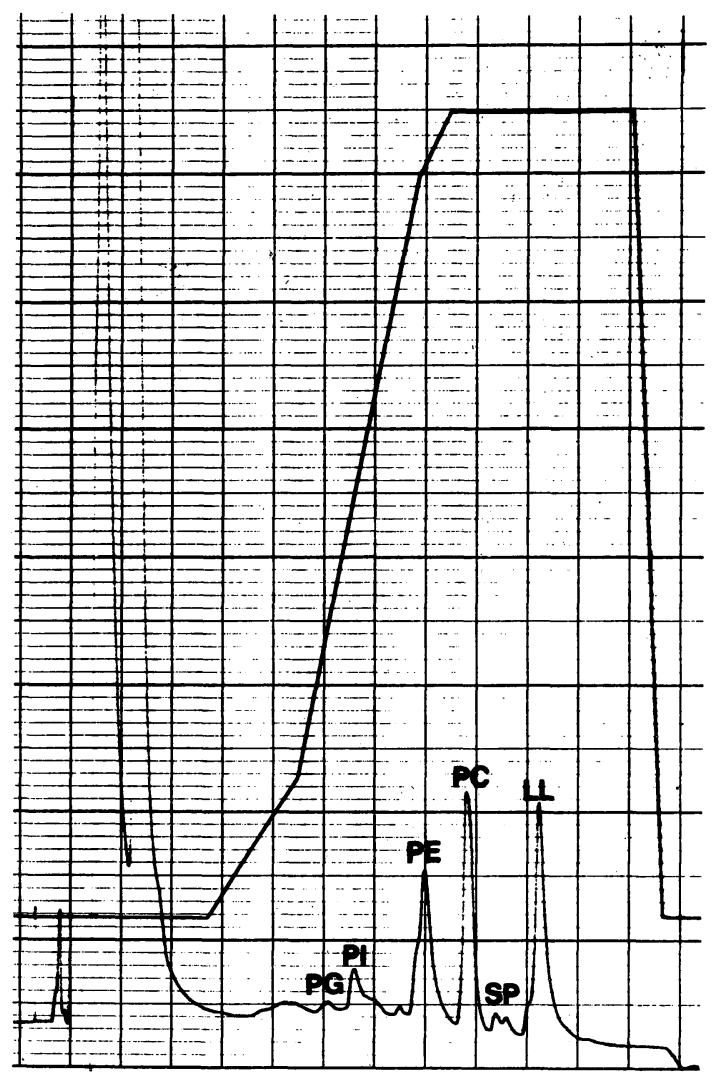

Figure 1. HPLC chromatogram of an amniotic fluid sample with tracing of the mobile phase of acetonitrilewater. form and methanol in the pro analysi quality for the extraction, and for the chromatography in the Lichrosolv quality from MERCK (Darmstadt, FRG). Furthermore aqua tridest is used.

\subsection{Preparation of the samples}

The clean up of amniotic fluid samples is different from the other media in some points and will therefore be described separately as follows:

\subsubsection{Amniotic fluid}

Amniotic fluid, either freshly withdrawn or stored at $-18^{\circ} \mathrm{C}$ is centrifuged for 10 minutes at $700 \mathrm{~g}$ $(2500 \mathrm{rpm}$ rotor radius $10 \mathrm{~cm}) .1,5 \mathrm{ml}$ of the supernatand is pipetted into a glass centrifuge tube with cut and point and mixed with $30 \mu \mathrm{g}$ lysolecithin as internal standard. A LL solution is used diluted with $2 \mu \mathrm{g} \mathrm{LL} / \mu \mathrm{g}$ chloroform-methanol 2:1 $(\mathrm{v} / \mathrm{v})$.

\subsubsection{Other media}

Since phospholipids are widespread in biological materials, it seemed very important to us to prove the validity of the method in different media. Consistency, viscosity, composition and concentrations of the various media differ in a broad spectrum. Therefore a comment should be made on the prepreparation of the samples and on the minimum amounts. Later the samples are dealt with in exactly the same way as amniotic fluid. However, the amounts of the single PL components, as the results given later will show, vary a lot.

Table I illustrates the 10 different media that have already been examined for their phospholipid content. Among these there are also some media taken

Table I. Table of examples for using phospholipid determination in various media

\begin{tabular}{llll}
\hline Medium & Species & Sample amount & Previous treatment \\
\hline Amniotic fluid & human & $1.5 \mathrm{ml}$ & centrifugated \\
Amniotic fluid & rat & $0.5-1.0 \mathrm{~g}$ & centrifugated \\
Tracheal secretion & human (newborn) & $\sim 0.5 \mathrm{~g}$ & homogenized \\
Tracheal secretion & sheep & $\sim 0.5 \mathrm{~g}$ & homogenized \\
Gastric aspirate & human (newborn) & $0.05-0.1 \mathrm{~g}$ & homogenized \\
Alveolar lavage & rat & $1.5 \mathrm{ml}$ & homogenized \\
Bronchial lavage & human (adult) & $1.5 \mathrm{ml}$ & homogenized \\
Milk & human & $0.2-0.5 \mathrm{~g}$ & homogenized \\
Milk & cow & $0.1-0.5 \mathrm{~g}$ & homogenized \\
Infant formulas & - & $0.1-0.5 \mathrm{~g}$ & \\
\hline
\end{tabular}


from animal material. The amounts can vary a lot according to their PL concentration. In cases of clear solutions only one previous centrifugation is necessary. Slimy or turbid media need to be homogenized before being dealt with, to enable a complete extraction. Alveolar lavages of the rat and bronchial lavages of the human being can show variable consistency - due to previous treatment, kind of illness or premedication. Samples may be clear, others can be extremely inhomogeneous. The latter must be homogenised in any case before the extraction. The minimum amount of amniotic fluid from rats should be $2 \mathrm{~g}$ if possible. However due to the small amount of amniotic fluid in pregnant rats this is mostly not available even when the amniotic fluid samples of a mother animal are pooled after cesarean section. The minimum of $0.5 \mathrm{~g}$ tracheal secretion of the newborn refers to undiluted samples. If the newborn has aspirated deeply, that is if the tracheal secretion is strongly diluted with amniotic fluid, then a larger amount of $1 \mathrm{~g}$ or more is necessary, due to the smaller PL concentrations. $100 \mathrm{ml}$ rinsing liquid - normally physiologic saline solution - is used for the alveolar lavages of rats and for the bronchial lavages of humans. Experience has shown that only about $60 \mathrm{ml}$ of the $100 \mathrm{ml}$ solution used can be recovered. $2 \mathrm{ml}$ of this amount should be dealt with at a time.

It should also be noted that LL cannot be used as the internal standard for samples that already contain lysolecithin. This is the case in some formulas, for example "APONTI 1" [5]. In such cases the whole amount of the bottom layer and the amount of the transferred aliquote have to be determined for the calculation of the absolute concentrations after extraction. Instead of the normal glass tubes graduated centrifuge tubes have to be used. The evaluation in these cases was made according to the $100 \%$ method (see chapter 2.4 ).

\subsection{Extraction}

$3.25 \mathrm{ml}$ chloroform, $2.75 \mathrm{ml}$ methanol and 1.50 $\mathrm{ml}$ of the centrifugate to be examined were pipetted into each tube. In serial runs the chloroformmethanol mixture can be mixed in advance at a ratio of 1.18:1 (for example, $325 \mathrm{ml}$ chloroform $+275 \mathrm{ml}$ methanol) in order to simplify the procedure. $6.0 \mathrm{ml}$ of this solution are used for each examination. The samples are sealed with a glass stopper, shaken by hand for 5 minutes and are deposited in an ice-bath for 5 minutes for better separation of layers. Then the samples are centri-

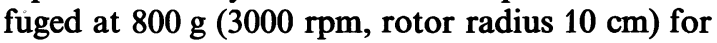
3 minutes. Afterwards the bottom layer is carefully removed using a $5 \mathrm{ml}$ disposable syringe with a canula $(0.9 \times 110 \mathrm{~mm})$ and transfered into another glass centrifuge pointed tube. One must take care that no contamination from the upper layer gets into the canula. This is done by carefully pressing some air out of the syringe into the solution when transferring the canula into the bottom layer. The bottom layer pipetted in this way is then evaporated by pure nitrogen to complete dryness. In order to accelerate this procedure, the samples are warmed up slightly in an air bath. After cooling of the glass centrifuge tube with ice for a short time, the residue is absorbed immediately in $100 \mu \mathrm{l}$ chloroform-methanol (Lichrosolv) at a ratio of $2: 1(\mathrm{v} / \mathrm{v})$ before being injected into the HPLC injection valve. $20 \mu \mathrm{l}$ of this solution are injected into the HPLC equipment at a time.

\subsection{Chromatographic analysis}

The phospholipids PG, PI, PE, PC, SP and LL obtained from the chloroform layer of the extraction are separated using HPLC equipment supplied by KNAUER (Berlin, FRG). The measuring unit consists of:

two HPLC pumps, an HPLC programmer, a column oven and a variable wavelength detector. Quantitation was carried out by integration of the peak areas by a SHIMADZU C-R3A integrator. To improve the quantitation of the chromatograms we supplemented the apparatus by using a television screen with an extra keyboard and floppy disc for storing the chromatograms.

For separation we used a $25 \mathrm{~cm} \times 0.46 \mathrm{~cm}$ column packed with $5 \mu \mathrm{m}$ Lichrosorb DIOL from MERCK (Darmstadt, FRG), and a $6 \mathrm{~cm} \times 0.46 \mathrm{~cm}$ guard column packed with $5 \mu \mathrm{m}$ Lichrosorb SI 60 and a sample enriching content packed with $7 \mu \mathrm{m}$ Lichrosorb SI 100, also from MERCK. The oven temperature was $55^{\circ} \mathrm{C}$ and the detection wavelength was $201 \mathrm{~nm}$. The mobile phase was composed of solvent A: acetonitrile and solvent B: acetonitrilewater $4: 1,(\mathrm{v} / \mathrm{v})$. The flow rate was constant at $2.5 \mathrm{ml} / \mathrm{min}$. The following solvent gradient was used: start with $\mathrm{A}=88 \%, \mathrm{~B}=12 \%$, from 5 until 7 minutes linear rise up to $B=23 \%$, from 8 to 11 minutes linear rise up to $B=70 \%$, from the beginning to the end of the 12th minute a linear rise up to $B=75 \%$. This mixture is kept on a constant 
level until the end of the 18 th minute. The content of $\mathrm{B}$ falls linearly to $12 \%$ during the 19 th minute. Figure 1 shows the tracing of the chromatogram and the described gradient course of an amniotic fluid sample taken in the 36th week of gestation.

Because the variable water content of the eluents produces an unstable baseline, all the chromatograms had to be baseline corrected. A blank chromatogram is traced for this purpose and is subtracted from the sample chromatogram by the computer. Depending on the LL-content there are two ways of quantitating the results:

a) automatic quantitation using the "internal standard method": we use LL as internal standard for quantitative determination of the phospholipids. This substance is particularly well suited for this examination. It has a suitable retention time and is normally below detection limit in the media examined. Quantitation occurs automatically using computer calculation giving single concentrations in $\mathrm{mg} / 100 \mathrm{ml}$. The calibration curve was achieved using a solution (chloroform-methanol $2: 1)$ containing $2 \mu \mathrm{g}$ of the phospholipids to be examined.

b) manual quantitation following the " $100 \%$ method": samples that already contain LL are extracted and measured without the addition of LL as internal standard. In these cases the quantitation is done according to the $100 \%$ method. The amounts of the single components are calculated through comparisons of the peaks of the samples with those of a standard mixture.

\section{Verification of the method}

\subsection{Linearity and detection limits}

The linearity of the measuring signals has already been proved in our earlier published examination [3]. When examining the standard solution there was a detection limit of $0.1 \mu \mathrm{g} / 100 \mathrm{ml}$ in all of the PL examined. In amniotic fluid the detection limits are at about $0.2 \mu \mathrm{g} / 100 \mathrm{ml}$. However if other biological materials like milk [5] or tracheal secretions [8] are examined, containing a high fat level or other interfering components, then the detection limits can even rise to above $0.3 \mu \mathrm{g} / 100 \mathrm{ml}$. Quantitation problems can occur in these cases due to superimposition particularly when determining PG on account of the enlargement of the peaks appearing first on the chromatogram.

\subsection{Recovery rates}

\subsubsection{Recovery rates in a standard mixture}

To determine the recovery rates in a standard mixture $15 \mu \mathrm{l}$ of a PL standard solution, containing $15 \mu \mathrm{g}$ of the phospholipids PG, PI, PE, PC, $\mathrm{SP}$ and LL were diluted with aqua tridest to 1.5 $\mathrm{ml}$ and were prepared and analysed as described in chapter 2.3 and 2.4. The results can be seen in table II. The levels for PG, SP and LL lie very close to the theoretical value of $100 \%$. This proves that LL is suitable as internal standard. In this trial the values for PE and PC were somewhat too high and the value for PI was clearly too low.

Table II. Recovery rates in a phospholipid standard solution

\begin{tabular}{|c|c|c|c|c|c|}
\hline \multirow[t]{2}{*}{ PL } & \multirow[t]{2}{*}{$\mathbf{N}$} & \multirow{2}{*}{$\begin{array}{l}\text { PL- } \\
\text { standard } \\
\text { added } \\
{[\mu \mathrm{g}]}\end{array}$} & \multicolumn{2}{|l|}{ found } & \multirow{2}{*}{$\begin{array}{l}\text { re- } \\
\text { covery } \\
\text { rate } \\
{[\%]}\end{array}$} \\
\hline & & & $\begin{array}{l}\overline{\mathrm{x}} \pm \mathrm{SD} \\
{[\mu \mathrm{g}]}\end{array}$ & $\begin{array}{l}\mathrm{CV} \\
{[\%]}\end{array}$ & \\
\hline PG & 8 & 15 & $15.35 \pm 0.83$ & 5.4 & 102.3 \\
\hline PI & 8 & 15 & $12.29 \pm 0.53$ & 5.4 & 81.9 \\
\hline PE & 8 & 15 & $17.06 \pm 0.65$ & 3.8 & 113.7 \\
\hline $\mathrm{PC}$ & 8 & 15 & $16.80 \pm 0.80$ & 4.7 & 112.0 \\
\hline SP & 8 & 15 & $15.84 \pm 0.87$ & 5.5 & 105.6 \\
\hline LL & 8 & 15 & $15.80 \pm 0.72$ & 4.6 & 105.3 \\
\hline
\end{tabular}

\subsubsection{Recovery rates in a dilution run}

To determine the recovery rates amniotic fluid samples from the 40th week of gestation were diluted in the ratio of $3: 1,1: 1$ respectively $1: 3$ $(\mathrm{v} / \mathrm{v})$ with samples of amniotic fluid from the 17th week of gestation. In this way the recovery rates can be checked under realistic and comparable conditions. The contents of the phospholipids examined in the original amniotic fluid samples are given in table III. In amniotic fluid from the 17th week of gestation PG lies below the detection limit. According to the fact that PI-production is foremost accelerated during the 2nd trimenon of pregnancy, PI-values are just above the detection limit. Table IV shows the amounts measured in the corresponding mixtures in $\mathrm{mg} / 100 \mathrm{ml}$. The recovery rates are given in table $\mathrm{V}$ in percentage. The levels fluctuate around the theoretical level of $100 \%$. Such fluctuations are justifiable in biological material. 


\subsection{Precision}

\subsubsection{Determination of the precision in a standard solution}

The precision of the series of runs and the precision from day to day in a standard solution of the phospholipids was determined to provide further statistical protection of the method. Table VI

Table III. Phospholipid contents (x) with standard deviations (SD) and coefficients of variation $(\mathrm{CV})$ of two amniotic fluid samples (40th week of gestation and 17th week of gestation) which are used for the dilution run

\begin{tabular}{|c|c|c|c|c|c|}
\hline \multirow[t]{2}{*}{ PL } & \multirow[t]{2}{*}{$\mathrm{N}$} & \multicolumn{2}{|c|}{ AF (40 wks gest) } & \multicolumn{2}{|c|}{ AF (17 wks gest) } \\
\hline & & $\begin{array}{l}\overline{\mathrm{x}} \pm \mathrm{SD} \\
{[\mathrm{mg} / 100 \mathrm{ml}]}\end{array}$ & $\begin{array}{l}\text { (CV) } \\
{[\%]}\end{array}$ & $\begin{array}{l}\overline{\mathrm{x}} \pm \mathrm{SD} \\
{[\mathrm{mg} / 100 \mathrm{ml}]}\end{array}$ & $\begin{array}{l}\text { (CV) } \\
{[\%]}\end{array}$ \\
\hline PG & 8 & $0.32 \pm 0.03$ & (9.5) & - & \\
\hline PI & 8 & $0.42 \pm 0.02$ & (4.7) & $0.05 \pm 0.01$ & (17.1) \\
\hline PE & 8 & $0.99 \pm 0.07$ & (7.1) & $0.49 \pm 0.02$ & (3.9) \\
\hline PC & 8 & $1.60 \pm 0.11$ & (6.9) & $0.42 \pm 0.01$ & (2.8) \\
\hline SP & 8 & $0.20 \pm 0.01$ & (5.0) & $0.49 \pm 0.02$ & (4.7) \\
\hline
\end{tabular}

shows the results. When determining the precision in the series 8 similar standard solutions are examined in one day. In this series $1 \mathrm{mg} / 100 \mathrm{ml}$ (corresponding to $15 \mu \mathrm{g}$ substance per examination) is added to each of the PL to be examined. The coefficient of variation (CV) fluctuates between $3.8 \%$ and $5.5 \%$ with a mean of $4.9 \%$. When determining the day to day precision, 5 samples were examined over 6 days. The CV values fluctuate between $3.4 \%$ and $16.8 \%$ with a mean of $5.5 \%$.

\subsubsection{Determination of the precision in amniotic fluid}

Mature amniotic fluid from the 36th week of gestation was examined to answer the question whether the precision of the method also meets the demands in this natural material. Table VII shows the results of the precision in the series of 11 samples examined. Here the CV fluctuates between $1.8 \%$ and $5.3 \%$, the mean is $3.1 \%$.

Table IV. Phospholipid contents (x) with standard deviation (SD) and coefficients of variation (CV) of a dilution run of the amniotic fluid samples described in table III

\begin{tabular}{|c|c|c|c|c|c|c|c|}
\hline \multirow[t]{3}{*}{ PL } & \multirow[t]{3}{*}{$\mathbf{N}$} & \multicolumn{6}{|c|}{ Mixing ratio of AF ( 40 wks gest): AF (17 wks gest) } \\
\hline & & \multicolumn{2}{|c|}{$3: 1$} & \multicolumn{2}{|l|}{$1: 1$} & \multicolumn{2}{|l|}{$1: 3$} \\
\hline & & $\begin{array}{l}\overline{\bar{x}} \pm \mathrm{SD} \\
{[\mathrm{mg} / 100 \mathrm{ml}]}\end{array}$ & $\begin{array}{l}\text { (CV) } \\
{[\%]}\end{array}$ & $\begin{array}{l}\overline{\mathrm{x}} \pm \mathrm{SD} \\
{[\mathrm{mg} / 100 \mathrm{ml}]}\end{array}$ & $\begin{array}{l}\text { (CV) } \\
{[\%]}\end{array}$ & $\begin{array}{l}\overline{\mathrm{x}} \pm \mathrm{SD} \\
{[\mathrm{mg} / 100 \mathrm{ml}]}\end{array}$ & $\begin{array}{l}\text { (CV) } \\
{[\%]}\end{array}$ \\
\hline PG & 6 & $0.19 \pm 0.02$ & (10.1) & $0.14 \pm 0.02$ & (10.9) & $0.07 \pm 0.01$ & (8.9) \\
\hline PI & 6 & $0.33 \pm 0.03$ & (9.3) & $0.22 \pm 0.02$ & $(8.7)$ & $0.13 \pm 0.02$ & (12.2) \\
\hline PE & 6 & $0.96 \pm 0.07$ & (7.1) & $0.89 \pm 0.06$ & (7.2) & $0.71 \pm 0.04$ & (5.3) \\
\hline PC & 6 & $1.20 \pm 0.03$ & (2.7) & $0.98 \pm 0.02$ & (1.6) & $0.84 \pm 0.01$ & (1.1) \\
\hline SP & 6 & $0.22 \pm 0.02$ & (8.1) & $0.36 \pm 0.01$ & (3.2) & $0.45 \pm 0.01$ & (1.4) \\
\hline
\end{tabular}

Table V. Recovery rates of a dilution run of the amniotic fluid samples described in table III

\begin{tabular}{lcccc}
\hline PL & N & \multicolumn{3}{l}{$\begin{array}{l}\text { mixing ratio of AF (40 wks gest): } \\
\text { AF (17 wks gest) }\end{array}$} \\
\cline { 3 - 5 } & & $\begin{array}{l}3: 1 \\
\text { recovery }\end{array}$ & $\begin{array}{l}1: 1 \\
\text { recovery }\end{array}$ & $\begin{array}{l}1: 3 \\
\text { rate }\end{array}$ \\
rate & $\begin{array}{l}\text { rate } \\
\text { ro] }\end{array}$ & {$[\%]$} & {$[\%]$} \\
\hline PG & 6 & 83.4 & 87.9 & 91.2 \\
PI & 6 & 98.6 & 91.8 & 92.4 \\
PE & 6 & 111.2 & 122.9 & 114.8 \\
PC & 6 & 92.3 & 96.9 & 117.6 \\
SP & 6 & 82.3 & 104.1 & 109.3 \\
\hline
\end{tabular}

Table VI. Precision in series and day to day precision of a phospholipid standard solution

\begin{tabular}{|c|c|c|c|c|c|}
\hline \multirow[t]{2}{*}{ PL } & \multirow[t]{2}{*}{$\mathbf{N}$} & \multicolumn{2}{|c|}{ within run precision } & \multicolumn{2}{|c|}{ between run precision } \\
\hline & & $\begin{array}{l}\overline{\mathrm{x}} \pm \mathrm{SD} \\
{[\mathrm{mg} / 100 \mathrm{ml}]}\end{array}$ & $\begin{array}{l}\text { (CV) } \\
{[\%]}\end{array}$ & $\begin{array}{l}\overline{\mathrm{x}} \pm \mathrm{SD} \\
{[\mathrm{mg} / 100 \mathrm{ml}]}\end{array}$ & $\begin{array}{l}\text { (CV) } \\
{[\%]}\end{array}$ \\
\hline & 8 & & & & \\
\hline & 8 & & 5. & & \\
\hline & 8 & & 3. & & \\
\hline & 8 & & 4. & & \\
\hline & 8 & $1.06 \pm 0.06$ & 5.5 & $1.02 \pm 0.03$ & 3.4 \\
\hline & 8 & $1.05+.0 .05$ & 4.6 & $1.00 \pm 0.07$ & 6.6 \\
\hline
\end{tabular}


Table VII. Precision in series and day to day precision of amniotic fluid samples (36th week of gestation)

\begin{tabular}{|c|c|c|c|c|c|}
\hline \multirow[t]{2}{*}{ PL } & \multirow[t]{2}{*}{$\mathbf{N}$} & \multicolumn{2}{|c|}{ within run precision } & \multicolumn{2}{|c|}{ between run precision } \\
\hline & & $\begin{array}{l}\overline{\bar{x}} \pm \mathrm{SD} \\
{[\mathrm{mg} / 100 \mathrm{ml}]}\end{array}$ & $\begin{array}{l}(\mathrm{CV}) \\
{[\%]}\end{array}$ & $\begin{array}{l}\overline{\mathrm{x}} \pm \mathrm{SD} \\
{[\mathrm{mg} / 100 \mathrm{ml}]}\end{array}$ & $\begin{array}{l}\text { (CV) } \\
{[\%]}\end{array}$ \\
\hline PG & 11 & $0.10 \pm 0.01$ & 6.5 & $0.10 \pm 0.01$ & 5.3 \\
\hline PI & 11 & $0.16 \pm 0.01$ & 3.6 & $0.17 \pm 0.01$ & 2.6 \\
\hline PE & 11 & $0.89 \pm 0.02$ & 1.7 & $0.87 \pm 0.03$ & 3.7 \\
\hline PC & 11 & $0.81 \pm 0.02$ & 3.0 & $0.82 \pm 0.01$ & 1.8 \\
\hline SP & 11 & $0.44 \pm 0.01$ & 3.1 & $0.43 \pm 0.01$ & 1.9 \\
\hline
\end{tabular}

\section{Results and discussion}

The results demonstrate that by improving the extraction procedure PE and PI can be quantitatively separated and so the second extraction step can be saved. In this way we gain about 40 minutes per analysis. This advantage is not offset by any disadvantage since the measured detection limits, the recovery rates and the precision both per day and the precision from day to day are as good as the results achieved in the method already described [3]. The sufficient precision and reliability

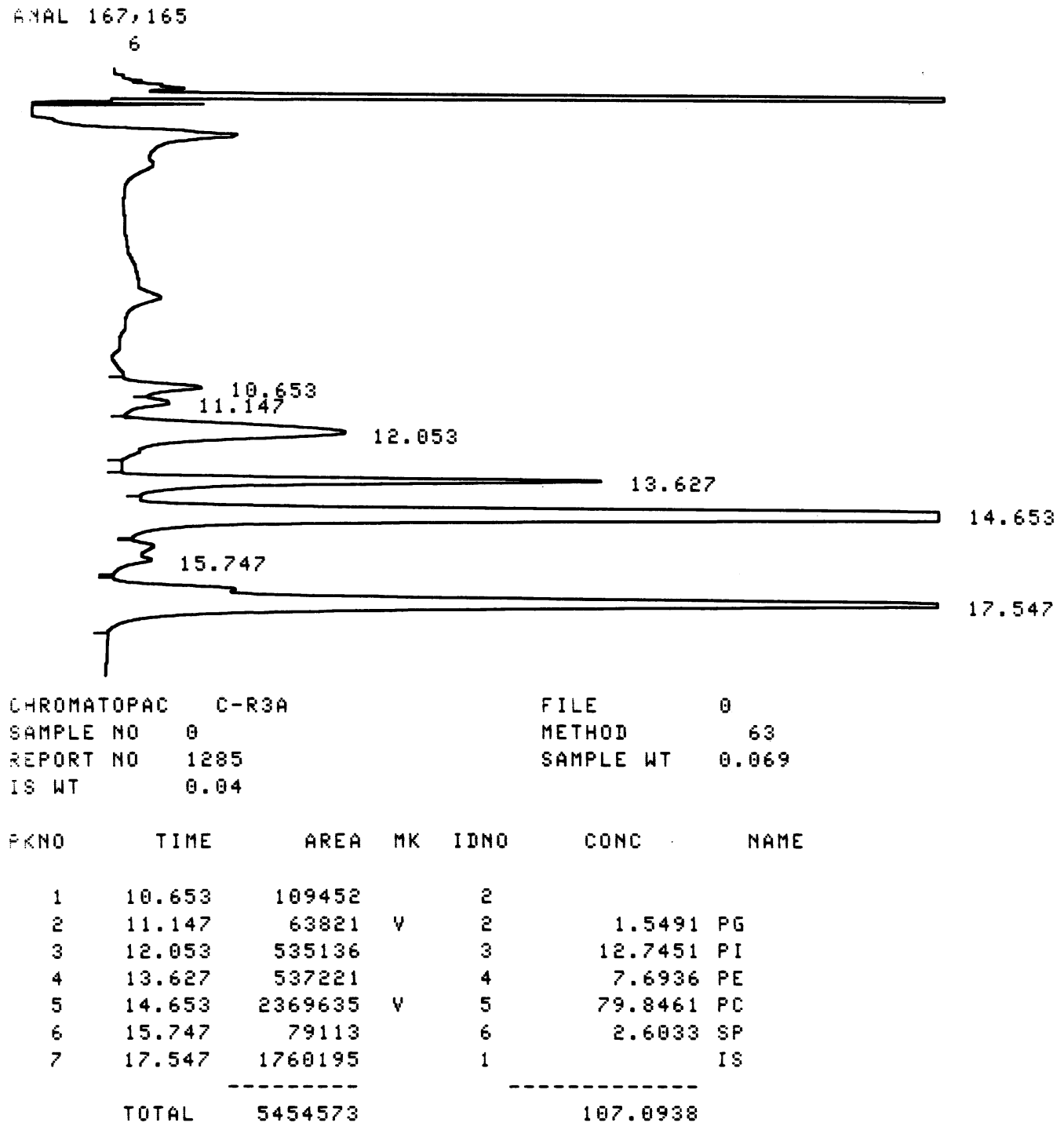

Figure 2. HPLC chromatogram and computer point of a bronchial lavage of an adult. 
of the method and the base to base separation of the PL components prove that there is no appreciable interference of $U V$ detection by unsaturated PL-components. The time required for a single analysis including blanks and measuring of the standard solution amounts to about two hours. When doing serial runs the time required is much less, so that per day up to 12 samples can be measured, and the time required per sample is reduced to about $\mathbf{4 0}$ minutes. A further important advantage of altering the method can be seen in the fact that the quantitative determination of the six mentioned phospholipids in other media than amniotic fluid is only practicable at all when there is no need for a second extraction. Without the proposed changes - as could be shown in various pretrials - the second extraction, according to the pattern of the old method [3] could not be performed at all in fatty media, such as milk and tracheal secretion. Furthermore LL is a suitable internal standard, since it is hardly ever present in biological material. Only in those cases the somewhat more time-consuming and less accurate $100 \%$ method has to be used for the extraction with exact determination of the sample volumes, as described in chapter 2.4 .

The chromatograms show sufficient separation of the peaks in all the media examined. The quantitation is of course difficult when certain components like PG or SP are only available in small quantities. Figure 2 shows the chromatogram of a bronchial lavage of an adult with low content of SP and a large amount of PC. Despite these great differences in concentration it is still possible in this case to get a sufficiently precise quantitation. Another example of the use of this method is given in the chromatogram of an infant formula (APONTI PRE), shown in figure 3. This product contains large amounts of PG. APONTI 1 on the other hand contains small amounts of LL. We have already reported on this result [5]. Further examinations will have to be made to prove the nutritional benefit of these components.

\footnotetext{
Abstract

A one step HPLC method for the determination of the main phospholipids, phosphatidylglycerol (PG), phosphatidylinositol (PI), phosphatidylethanolamine (PE), phosphatidylcholine (PC), sphingomyelin (SP) and lysolecithin (LL) in amniotic fluid, milk, tracheal secretion, lung lavages, gastric aspirates, infant formulas and some other human and animal media has been developed.
}

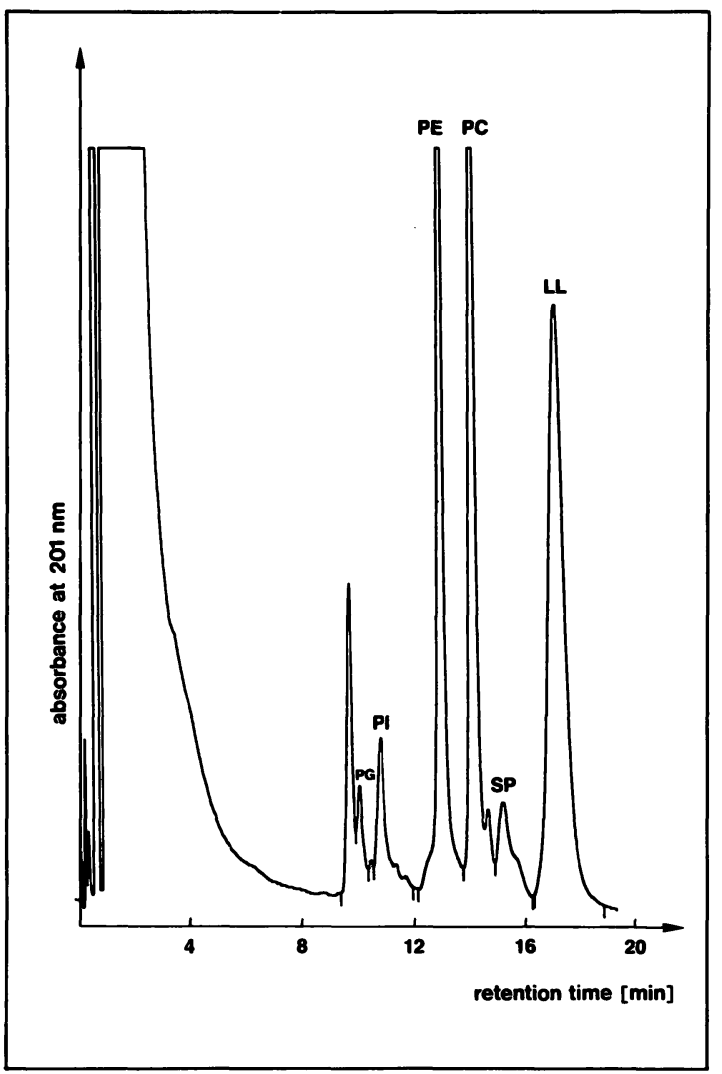

Figure 3. HPLC chromatogram of an infant formula (APONTI PRE).

In summarizing the results it can be said that the HPLC method for determining the main phospholipids described here is an improvement compared to previous procedures and is able to detect the main phospholipids specifically and quantitatively in other biological media recently with standard HPLC equipment. Phospholipids carry an important function in many spheres of medicine. The improvement in specific, quantitative methods for their determination is therefore of great importance.

Quantitation occurs automatically using computer calculation and lysolecithin as an internal standard. Detection limits are at about $0.2 \mu \mathrm{g} / 100 \mathrm{ml}$ but may rise to about $0.3 \mu \mathrm{g} / 100 \mathrm{ml}$ in cases of high fat levels or other interfering compounds. Recovery rates measured in amniotic fluid fluctuate around the $100 \%$ level.

Time required for a single analysing including a blank 
run and a calibration standard solution measurement amounts to about two hours. In series analysis 12 samples per day can be examined, while the required time per sample is reduced to 40 minutes.
As phospholipids carry an important function in many spheres of medicine, the improvement in specific quantitative determination of these compounds is of great importance.

Keywords: Amniotic fluid, fetal lung maturity, high performance liquid chromatography (HPLC), lung lavages, milk, phospholipids, tracheal secretion.

\section{Zusammenfassung}

Vereinfachte quantitative Bestimmung von Phospholipiden in Fruchtwasser, Alveolarlavagen und Milch mittels Hochdruckflüssigkeitschromatographie (HPLC)

Durch Einführung der Hochdruckflüssigkeitschromatographie (HPLC) in die Analytik der Phospholipide (PL) ist es möglich geworden, die Hauptphospholipide im Fruchtwasser quantitativ und mit hoher Empfindlichkeit $\mathrm{zu}$ bestimmen. So konnten durch Einführung der HPLC erhebliche Fortschritte bei der Bestimmung der fetalen Lungenreife, die eines der Hauptprobleme der Perinatologie darstellt, erreicht werden. Die Phospholipide sind nicht nur im Fruchtwasser von Bedeutung, sondern stellen ein biochemisches Problem von allgemeinem Interesse dar. Daher schien es sinnvoll, die Anwendbarkeit der HPLC-Methode auch für andere biologische Medien wie Trachealsekret, Magensaft, Lungenlavagen, Mutter- und Kuhmilch sowie Säuglingsnahrungen zu überprüfen. Die hierzu notwendigen Verbesserungen und Veränderungen der Methode lassen sich in zwei Punkten zusammenfassen:

1. Veränderung des Extraktionsverfahrens zur Verbesserung der Extraktion von Phosphatidyläthanolamin (PE) und Phosphatidylinositol (PI), um eine zweite Extraktion überflüssig zu machen. Diese zweite Extraktion ist sehr zeitaufwendig und bei anderen Medien wie Milch und Trachealsekret wegen der vielen weiteren Bestandteile nicht durchführbar.

2. Verbesserung der Phasentrennung, da es zum Beispiel bei stark mekoniumhaltigen Fruchtwasserproben zu keiner Trennung der Extraktionsphasen kommt.

Tabelle I zeigt in der Übersicht 10 verschiedene Medien, die auf ihren Phospholipidgehalt bereits untersucht wurden. Darunter sind auch einige Medien, die aus tierischem Material gewonnen wurden. Je nach Konzentration können die Einsatzmengen stark variieren. Bei klaren Lösungen ist zur Vorbereitung nur das Zentrifugieren notwendig. Wenn es sich um schleimige oder trübe Medien handelt, muß dagegen vor der Aufarbeitung homogenisiert werden, um eine vollständige Extraktion zu ermöglichen. Die bei der Extraktion gewonnenen Phospholipide, Phosphatidylglycerol (PG), Phosphatidylinositol (PI), Phosphatidyläthanolamin (PE), Phosphatidylcholin (PC), Sphingomyelin (SP) und Lysolezithin (LL) werden mit einer HPLC-Anlage der Firma KNAUER (Berlin) getrennt. Die quantitative Auswertung erfolgt durch Integration der Peakflächen mittels eines Integrators der Firma SHIMADZu C-R3A. Zur besseren Auswertung der Chromatogramme haben wir die Anlage durch ein Bildschirm-Sichtgerät mit Extratastatur und
Floppydisk zur Chromatogrammspeicherung ergänzt. Da der unterschiedliche Wassergehalt der Eluenten einen Anstieg der Grundlinie verursacht, müssen alle Chromatogramme basislinienkorrigiert werden. Abhängig vom LL-Gehalt der Proben gibt es zwei Möglichkeiten zur quantitativen Auswertung der Ergebnisse:

a) automatische Auswertung nach der ,internen Standardmethode"

b) manuelle Auswertung nach der „100\% Methode“.

Im Fruchtwasser liegen die Nachweisgrenzen bei etwa $0,2 \mu \mathrm{g} / 100 \mathrm{ml}$. Werden jedoch andere biologische Materialien wie etwa Milch mit sehr hohem Anteil an Fetten oder anderen Fremdstoffen untersucht, so können in ungünstigen Fällen die Nachweisgrenzen auf über 0,3 $\mu \mathrm{g} / 100 \mathrm{ml}$ steigen. Die Ergebnisse zeigen, daß durch Verbesserung des Extraktionsverfahrens PI und PE ausreichend quantitativ extrahiert werden und so der zweite Extraktionsschritt eingespart werden kann. Dadurch wird pro Analyse ein Zeitgewinn von etwa 40 Minuten erreicht. Dieser Vorteil wird durch keine Nachteile erkauft, denn die gemessenen Nachweisgrenzen, Wiederfindungsraten und die Präzision sowohl am Tage, als auch die Präzision von Tag zu Tag sind genausogut wie die Werte der bereits beschriebenen Methode [3]. Die ausreichenden Werte für Präzision und Wiederfindung und die Basislinientrennung der PL Komponenten beweisen, daß keine ins Gewicht fallende Störung der UV Detektion durch ungesättigte Phospholipidkomponenten erfolgt. Der Zeitaufwand für eine Einzelanalyse beträgt mit Leerkurve und Messung des Standardgemisches etwa zwei Stunden. Bei Serienmessungen verkürzt sich der Zeitaufwand erheblich, so daß pro Tag bis zu 12 Proben gemessen werden können, womit der Zeitaufwand pro Probe auf etwa 40 Minuten sinkt. Die Chromatogramme zeigen bei allen untersuchten Medien eine ausreichende Trennung der Peaks. Schwierig wird die Auswertung dann, wenn bestimmte Komponenten, wie PG oder SP nur in sehr geringen Mengen vorhanden sind.

Abb. 2 zeigt das Chromatogramm einer Bronchiallavage eines erwachsenen Menschen mit geringem Gehalt an SP und hohem Gehalt an PC. Trotz der großen Konzentrationsunterschiede ist auch in diesem Fall eine ausreichend genaue Auswertung möglich. Ein weiteres Beispiel für die Anwendung der Methode zeigt Abb. 3 mit der Darstellung des Chromatogramms einer Säuglingsnahrung (APONTI PRE). Dieses Produkt enthält hohe Mengen an PG. 
Die vorliegende HPLC-Methode zur Bestimmung der Phospholipide stellt eine deutliche Verbesserung gegenüber dem bisher bekannten Verfahren dar und ist in der Lage auch in anderen biologischen Medien die Haupt- phospholipide spezifisch und quantitativ nachzuweisen. $\mathrm{Da}$ die Phospholipide in vielen Bereichen der belebten Natur wichtige Funktionen innehaben, kommt der Verbesserung ihrer Analytik ein hoher Stellenwert zu.

Schlüsselwörter: Fruchtwasser, Hochdruckflüssigkeitschromatographie (HPLC), Lungenlavagen, Lungenreife, Milch, Phospholipide, Trachealsekret.

\section{Résumé}

Détermination quantitative simplifiée des phospholipides dans le liquide amniotique, les produites de lavage alveolaires et le lait à l'aide de chromatographie en phase liquide a haute performance (HPLC)

Il est devenu possible de détecter quantitativement les phospholipides (PL) principaux dans la liquide amniotique avec une sensibilité élevée par l'introduction de la chromatographie en phase liquide à haute performance (HPLC) pour l'analyse des PL. C'est ainsi que l'HPLC a permis des progrès pour la détermination de la maturité pulmonaire fotale qui représente un des problèmes principaux en périnatologie.

Du fait qu'on ne trouve pas seulement les phospholipides dans le liquide amniotique sur lequel plusieurs méthodes de détermination par HPLC ont été mises au point ils sont d'un intérêt général. C'est pourquoi il semble important de faire le bilan de la validité des méthodes par HPLC dans d'autres liquides biologiques tels que les produits de secrétion trachéale, le liquide d'aspiration gastrique, les produits de lavage pulmonaire, le lait humain et le lait de vache ainsi que dans les laits pour enfants. L'amélioration et les modifications nécessaires peuvent être résumées en deux points.

a) modification des techniques d'extraction pour compléter l'extraction de la phosphatidylethanolamine (PE) et du phosphatidylinositol (PI) afin de rendre superflue une deuxième extraction. Cette seconde extraction prend beaucoup de temps et ne peut être réalisée dans des milieux tels que de lait et les produits de secretion trachéale du fait de la présence d'autres substances telles que celles à haute teneur en graisse.

b) amélioration de la séparation en couches du fait qu'il n'y a pas de séparation des couches d'extractions dans les liquides amniotiques contenant beaucoup de méconium.

Le tableau I illustre les $\mathbf{1 0}$ différents milieux dont on a déjà étudié la teneur en phospholipides. Parmi ceux-ci, certains milieux proviennent de matériels animaux. Les quantités peuvent varier largement selon la concentration des PL. Dans les cas où on dispose de solutions nettes, une seule centrifugation préliminaire est nécessaire. Les milieux visqueux nécessitent une homogénisation préalable pour que soit possible une extraction complète.

Les phospholipides phosphatidylglycerol (PG), phosphatidylinositol (PI), phosphatidyléthanolamine (PE), phosphatidylcholine (PC), sphingomyeline (SP) et lysolecithine (LL) obtenus par extraction sont séparés à l'aide du matériel à HPLC fournis par KNAUER (Berlin,
RFA). La quantification est menée à bien par intégration des aires des pics par un intégrateur Shimadzu C-R 3A. Pour améliorer la quantification des chromatogrammes nous améliorons l'appareillage en nous servant d'un écran de télévision avec un clavier et des disquettes pour stocker les chromatogrammes. Comme la teneur des éluats en eau est variable provoque une ligne de base instable, il faut corriger la ligne de base de tous les chromatogrammes.

Il y a deux modes de quantification des résultats quant à la teneur en LL:

a) quantification automatique en utilisant LL comme standard interne.

b) quantification manuelle en suivant la méthode des $100 \%$ pour les échantillon contenant déjà $L L$.

Dans le liquide amniotique, les limites de détection sont d'environ $0,2 \mu \mathrm{g} / 100 \mathrm{ml}$. Toutefois, si l'on étudie d'autres matériels biologiques comme le lait ou les produits de sécrétions trachéales qui contiennent des taux élevés de graisse ou d'autres composants qui interfèrent, les limites de détection peuvent alors s'élever au-dessus de $0,3 \mu \mathrm{g} /$ $100 \mathrm{ml}$.

Les résultats démontrent qu'en améliorant la technique d'extraction, on peut séparer quantitativement PE et PI et ainsi éviter l'étape de la seconde extraction. Et par là, le gain est de $\mathbf{4 0}$ minutes par analyse. Cet avantage n'est pas contrebalancé par quelque désavantage puisque les limites de détection mesurées, les taux de récupération ainsi que la précision qu'elle soit quotidienne ou jour après jour sont aussi bons que les résultats obtenus par les méthodes déjà décrites [3]. La précision et la fiabilité suffisantes de la méthode et la séparation base par base des composants PL prouvent qu'il n'y a pas d'interférence appréciable de détection UV avec les composants PL insaturés. Le temps nécessaire pour une seule analyse comprenant la mise à zéro et la mesure des échantillons standards représente environ 2 heures. Lorsqu'on effectue des examens en série le temps nécessaire est nettement moindre de telle sorte que l'on peut mesurer chaque jour jusqu'à 12 échantillons et le temps nécessaire par échantillon se réduit à environ $\mathbf{4 0}$ minutes.

Les chromatogrammes montrent une séparation suffisante des pics pour tous les milieux examinés. La quantification est de fait difficile lorsque certains composants tels que PG ou SP n'existent qu'en faible quantité. La figure 2 montre les chromatogrammes d'un lavage bronchique d'un nouveau-né avec une faible teneur en SP et de grandes quantités de PC. Malgré ces grandes différences de concentration, il est encore possible dans ce 
cas d'obtenir une quantification suffisemment précise. Un autre exemple de l'utilisation de cette méthode est fourni par les chromatogrammes d'un lait pour bébé, montré dans la figure 3 . Ce produit contient de grandes quantités de $\mathrm{PG}$.

La méthode proposée représente une amélioration en comparaison des techniques précédentes et est capable de détecter les phospholipides principaux tant spécifiquement que quantativement dans d'autres milieux biologiques, celà de façon récente avec un équipement standard HPLC. Comme les phospholipides supportent une fonction importante dans de nombreuses sphères médicales, l'amélioration des méthodes spécifiques et quantitatives de dosage revet une grande importance.

Mots-clés: Chromatographie en phase liquide à haute performance (HPLC), lait, lavages pulmonaires, liquide amniotique, maturité pulmonaire fœtale, phospholipides, sécrétion trachéale.

\section{References}

[1] ANDREws AG:Estimation of amniotic fluid phospholipids by high-performance liquid chromatography. J Chromatography 336 (1984) 139

[2] D'Costa M, R DAssin, H BRYAN, P Joutsi: Validation of a simple rapid high performance liquid chromatographic method for amniotic fluid lecithin/ sphingomyelin ratios. Clin Biochem 18 (1985) 27

[3] Heinze T, G Kynast, JW Dudenhausen, C Schmitz, E Saling: Quantitative determination of phospholipids in amniotic fluid by high-performance liquid chromatography. Chromatographia 25 (1988) 497

[4] Iтон K, A Suzuki, Y Kuroki, T AkIno: High performance liquid chromatographic separation of diacylglycerol acetates to quantitate disaturated species of lung phosphatidylcholine. Lipids 20 (1985) 611

[5] Kynast G, C Schmitz: Determination of the phospholipid content of human milk, cow's milk and various infant formulas by high performance liquid chromatography (HPLC). Z Ernährungswiss 27 (1988) 252

[6] Pison U, E Gono, T Joka, U Obertacke, M OblaDEN: High-performance liquid chromatography of adult human bronchoalveolar lavage: Assay for phospholipid lung profile. J Chromatography 377 (1986) 79
[7] Postle AD: Method for the sensitive analysis of individual molecular species of phosphatidylcholine by high-performance liquid chromatography using post-column fluorescence detection. J Chromatography 415 (1987) 241

[8] Schmitz C, S Schmidt, G Westphal, G Kynast, JW Dudenhausen: Veränderungen des Phospholipidgehaltes im Trachealsekret des neugeborenen Schafes während extrakorporaler Perfusion. In: DuDENHAuSEN JW, E Saling: Perinatale Medizin Band XII. Thieme, Stuttgart 1988

[9] Sotirhos N, C ThÖRngREN, B HeRsLöF: Reversedphase high-performance liquid chromatographic separation and mass detection of individual phospholipid classes. J Chromatography 331 (1985) 313

Received October 10, 1988. Accepted April 4, 1989.

Dr. med. Dr.-Ing. Geno Kynast

Institut für Perinatale Medizin

Freie Universität Berlin

Mariendorfer Weg 28

D-1000 Berlin 44

West Germany 